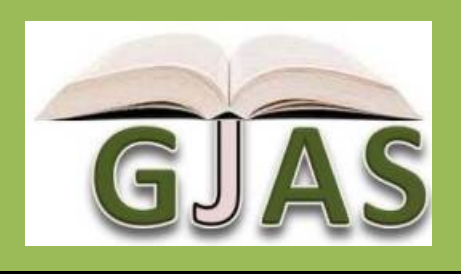

\title{
Performance of Conventional and Locally Fabricated Chisel Plows in Canefields of the Sudanese Sugar Company
}

\author{
Hammad E. A. ${ }^{1}$, Obeid A. ${ }^{2}, \mathrm{~A} /$ Gadir S. ${ }^{3}$ and Idris S. A. ${ }^{4}$ \\ ${ }^{1}$ Faculty of Agricultural Technology, University of Alneelain, Khartoum, Sudan. \\ ${ }^{2,3,4}$ Sugarcane Research Centre (SCRC), Sudanese Sugar Company (SSC).
}

\section{ARTICLE INFO}

Article No.: 070913714

DOI: 10.15580/GJAS.2013.3.070913714

Submitted: 09/07/2013

Accepted: 22/07/2013

Published: 29/07/2013

${ }^{\star}$ Corresponding Author

E. A. Hammad

E-mail: Bashir.Hammad58

@gmail.com

Phone: +249 912551822

Keywords:

Chisel plow, field performance,

ratoon cane, Sudanese Sugar

Company

\section{ABSTRACT}

Field performance of a conventional 6-shank chisel plow of a Turkish origin supplied by Giad Company (Sudan) and two chisel plows with 6 and 10 vertical shanks locally fabricated in workshops of the Sudanese Sugar Company (SSC) was studied under conditions of ratoon fields of the SSC. Performance parameters were field capacity, drawbar pull, fuel/ha and energy/ha. Results showed that Giad plow provided higher field capacity (3.6 ha/h), required lowest drawbar pull $(7.8 \mathrm{kN})$, lowest fuel consumption (5.24 L/ha) and lowest energy (7.62 kW-h/ha). Values obtained with the local 6-shank chisel plow expressed as percentages of Giad plow were respectively $96.3 \%, 119.2 \%, 126.7 \%$ and $121.9 \%$. For the 10 -shank local chisel plow, respective values were $93 \%, 143.6 \% 136.2 \%$ and $146.9 \%$. Resulting furrow surfaces produced by the three plows were practically similar. 


\section{INTRODUCTION}

The Sudanese Sugar Company (SSC) is a governmental body comprising four sugarcane estates within the Central Clay Plain situated between Latitude $16^{\circ}$ and $10^{\circ}$ North and Longitudes $32^{\circ}$ and $37^{\circ}$ East. Area under cane is approximately 36500 ha. Adopted sugarcane production cycle consists of a plant crop and three to four annual ratoons.

Land preparation for sugarcane planting includes successive operations with heavy offset disc harrows and secondary tillage implements to provide ridge and furrow system for placement and covering of cane setts in the furrows. When the new plant is about four months of age, soil from the inter-rows is chisel ploughed and pushed to the sides of the cane rows to build ridges around them and to transform former ridges into furrows; an operation called hilling up. For ratoon fields, main cultural operations are broadcasting of granular urea, incorporation of urea in furrows between the cane rows and maintenance of the ridge and furrow system.

Chisel plows with 6 and 10 vertical shanks, fabricated in workshops of the sugar estates, are the implements used to loosen the soil for the hilling up operation and the incorporation of urea in ratoon fields. Mild steel is the material used in the fabrication of those plows because it is malleable, available in the local markets and relatively cheap. However, mild steel has low tensile strength (Wikipedia 1,2013 ) to the extent that plows were frequently deformed or damaged during normal work. Modern chisel plows normally have two or more rows of curved spring-steel shanks attached to a rugged box-steel frame (Deere \& Company, 1993). Spring steel is a low alloy, medium carbon steel or high carbon steel with very high yield strength (Wikipedia 2 , 2013). Spring steel allows the shanks to return to their original shape despite significant bending or twisting.

Implement fabrication workshops of the SSC were poorly equipped, mainly dependent on simple arc welding machines and Oxy- Acetylene cutting torches. Metal bending machines, fabrication tools and precision measuring devices were rarely available. However, for more than two decades, those workshops strived to provide indigenous solutions for many field requirements. Almost all chisel plows, furrowers and fertilizer applicators were somehow fabricated in those workshops.

As normal development in agricultural equipment markets, now in Sudan there are suppliers who provide properly designed and manufactured machinery for cane farming. To make the economically right choice, decision makers in the Sudanese sugar sector need to have information about the performance of their fabricated implements and of those provided by specialized manufacturers. Of special importance in this respect is the draft requirement. According to Landers (2000), a good method of tractor selection, based upon scientific fact, is to consider soil type and the draft requirement for different types of cultivation equipment. Although guidelines for selection of tractors and implements for canefield in Sudan were recently proposed (Hammad, 2012), actual performance data remains a reliable base for machinery management for each specific condition.

The objective of this work was to study the performance of locally fabricated chisel plows with 6 and 10 shanks and that of a conventional chisel plow with 6 shanks provided by Giad Company for Tractors and Agricultural Equipment. Main field performance parameters were implement draft, actual field capacity, fuel consumption, energy required and resulting furrow surface.

\section{MATERIALS AND METHODS}

Chisel plows and test conditions:

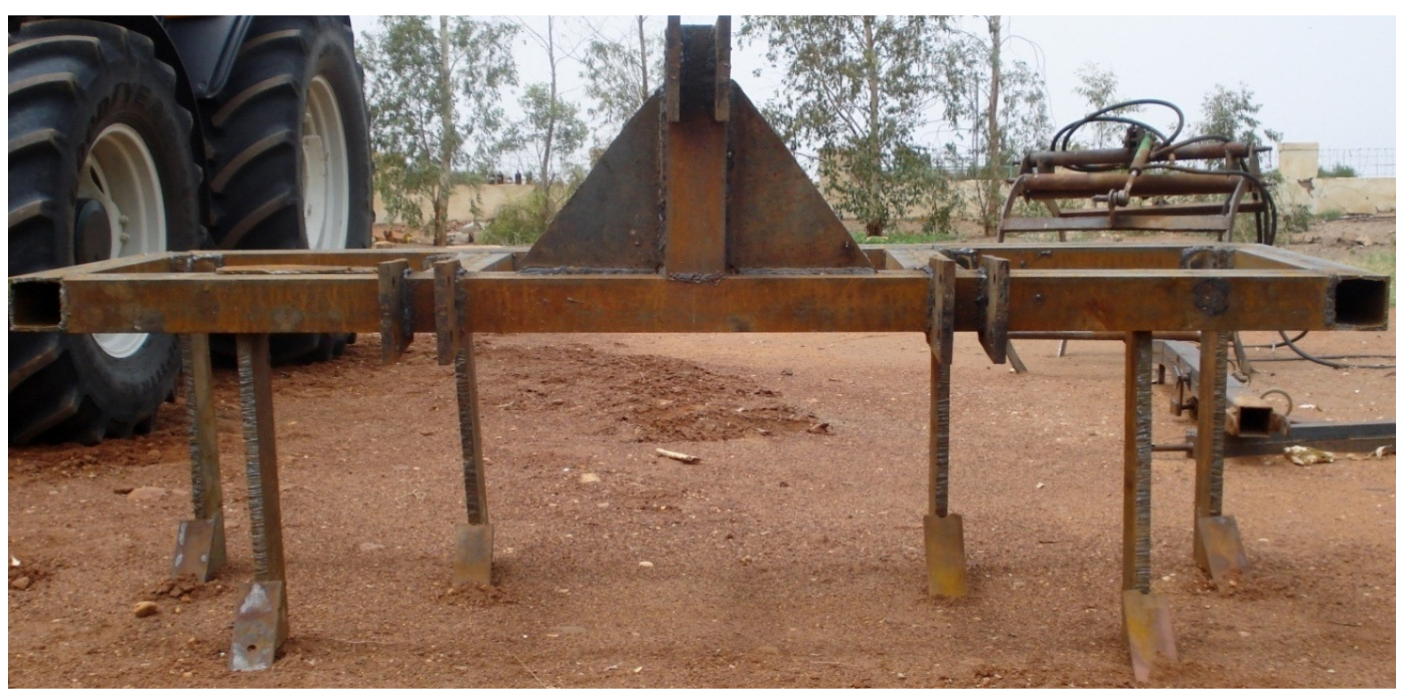

Figure 1: Locally fabricated 6-shank chisel plow 


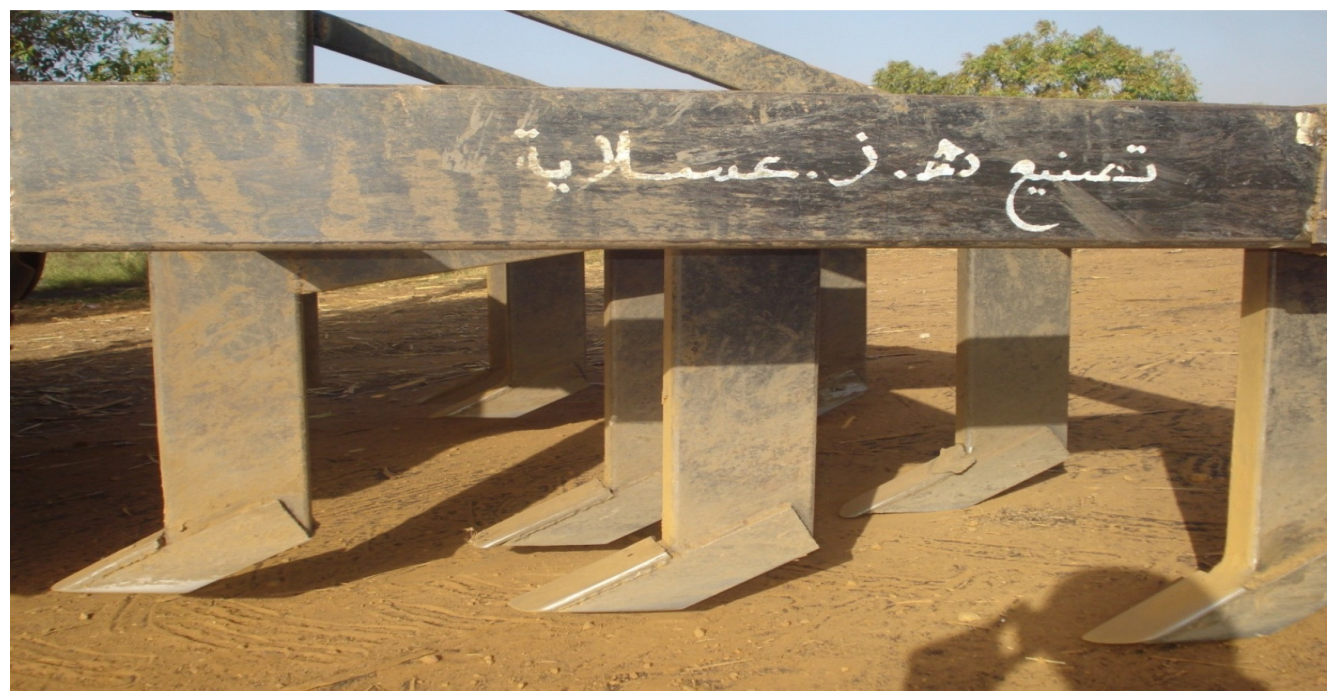

Figure 2: Locally fabricated 10-shank chisel plow

Two chisel plows locally fabricated by the SSC, one with six vertical shanks (Figure 1) and another with 10 vertical shanks (Figure 2) in addition to a third chisel plow (of a Turkish origin) with six approximately curved shanks (Figure 3) supplied by Giad Company (Sudan), were used in this study. The locally fabricated chisel plows consisted of welded parts with no protection devices. For Giad plow, each shank was attached with two bolts to a mounting bracket fixed to the main frame. One of the two bolts was smaller in diameter than the other. Under shock loads, the smaller bolt fails to allow the shank pivot around the other bolt and move outwards from the soil. The three chisel plows were 2furrow, tractor-mounted implements. Space between shanks was $30 \mathrm{~cm}$ for the local 6-shank and Giad plows and it was $15 \mathrm{~cm}$ for the 10-shank local plow. Weight of the plows is shown in Table 3. The plows are respectively referred to hereafter as Giad, 6-shank and 10-shank chisels.

Performance parameters were measured during chiseling operations in ratoon fields in two sugarcane estates during the period extending from December 2012 to March 2013. In the two estates, six test locations comprising 54 test plots of ratoon cane were used. In each location, tests were replicated three times for each of the three chisel plows. A test plot was from 16 to 20 furrows wide (24 to $30 \mathrm{~m}$ ) and 120 to 200 $\mathrm{m}$ long according to location. Bottoms of the furrows were firm, nearly flat and approximately $60 \mathrm{~cm}$ wide. Centre to centre distance of two adjacent furrows was 1.5 to $1.55 \mathrm{~m}$.

\section{Measurement of performance parameters:}

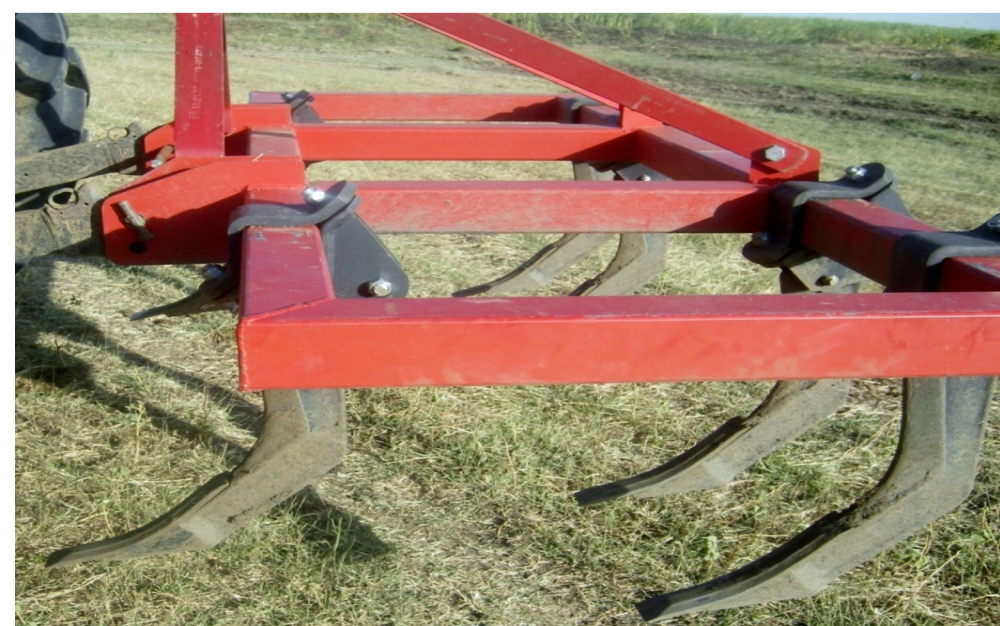

Figure 3: Giad chisel plow (of a Turkish origin)

Draft requirement of the plows was measured with a hydraulic pull-meter. A tractor carrying a plow was pulled by another tractor with the pull-meter connected between the two tractors. The hydraulic system of the rear tractor was used to raise and lower the plow as required for normal operation, with the transmission system kept in neutral. In this arrangement, drawbar force for pulling the rear tractor and implement was supplied by the towing tractor. Rolling resistance of the rear tractor was determined by pulling the tractor with the implement raised. Difference between the two measurements was the net drawbar pull for the 
implement under study. Pull meter readings were averaged over a distance of 240 to 400 meters (two runs across the field). For measuring field capacity, dimensions of each plot were measured with a measuring tape and time needed to chisel the area was determined with a stopwatch. To calculate actual speed of operation, time to travel $100 \mathrm{~m}$ along the field was measured while the ploughs were working on the test plots. Resulting furrow surface was physically judged by the working team. For measuring fuel consumption, fuel tank of the tractor carrying an implement was topped up at the start of the work on a plot, and then topped up

again using a graduated measuring cylinder after chiseling the plot.

Soil samples were collected from some fields to measure the range of gravimetric soil moisture content encountered during chisel ploughing. Composite samples from $00-30 \mathrm{~cm}$ depth were analyzed in the soil laboratory of Alneelain University (Sudan) to determine the type of soils in the tow estates.

\section{RESULTS AND DISCUSSION}

Table 1: Gravimetric soil moisture content

\begin{tabular}{|l|l|}
\hline $\begin{array}{l}\text { Depth } \\
(\mathrm{cm})\end{array}$ & $\begin{array}{l}\text { Soil moisture } \\
\text { content }(\%)\end{array}$ \\
\hline $00-10$ & $18.6-24.6$ \\
\hline $10-20$ & $22.9-29.3$ \\
\hline $20-30$ & $24.0-30.4$ \\
\hline
\end{tabular}

Table 2: Soil structure of sugarcane estates

\begin{tabular}{|l|l|l|}
\hline Soil particles & $\begin{array}{l}\text { Sugarcane } \\
\text { estate (1) }\end{array}$ & $\begin{array}{l}\text { Sugarcane } \\
\text { estate (2) }\end{array}$ \\
\hline Sand (\%) & 21 & 35 \\
\hline Silt (\%) & 24 & 23 \\
\hline Clay (\%) & 55 & 53 \\
\hline
\end{tabular}

Ranges of soil moisture encountered during the tests are shown in Table 1. Soil analysis is shown in Table 2. Soil in both estates was of the clay type. Average speed was $12.5 \mathrm{~km} / \mathrm{h}$ for Giad and the 6-shank chisels and was $11.9 \mathrm{~km} / \mathrm{h}$ for the 10 -shank chisel. Average values of other performance parameters are shown in Figure 4 to Figure 7.

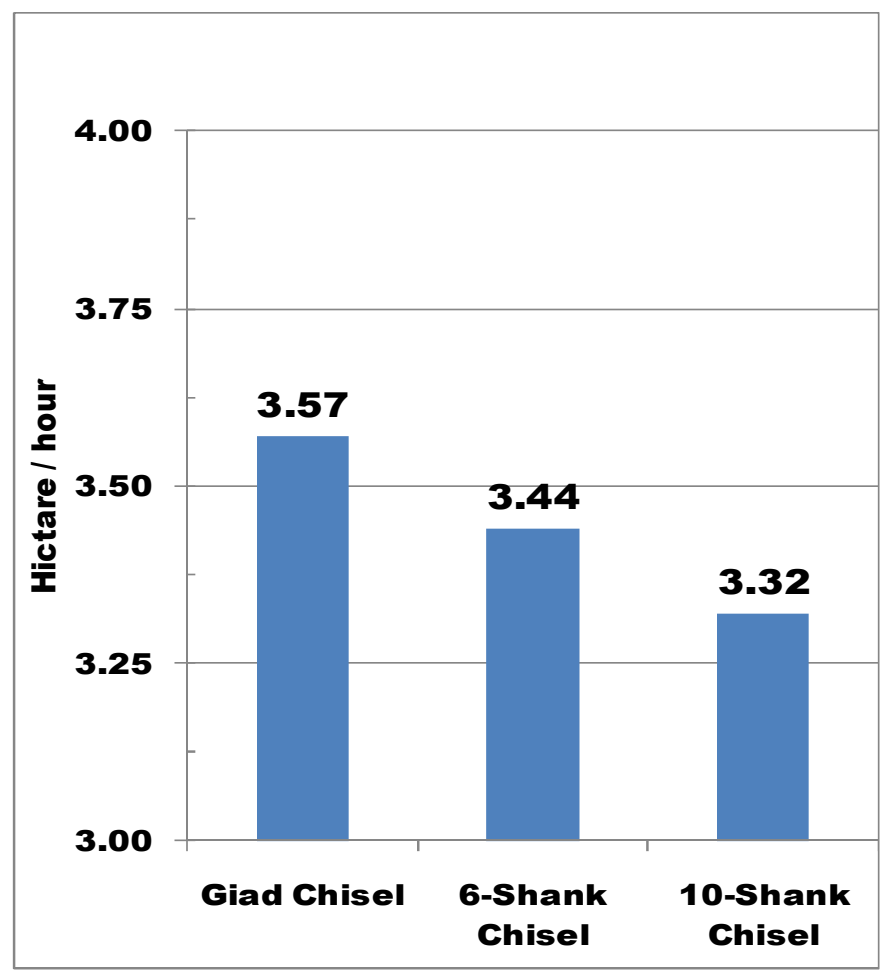

Fig 4: Field capacity of 3 chisel plows in sugarcane estates in Sudan 


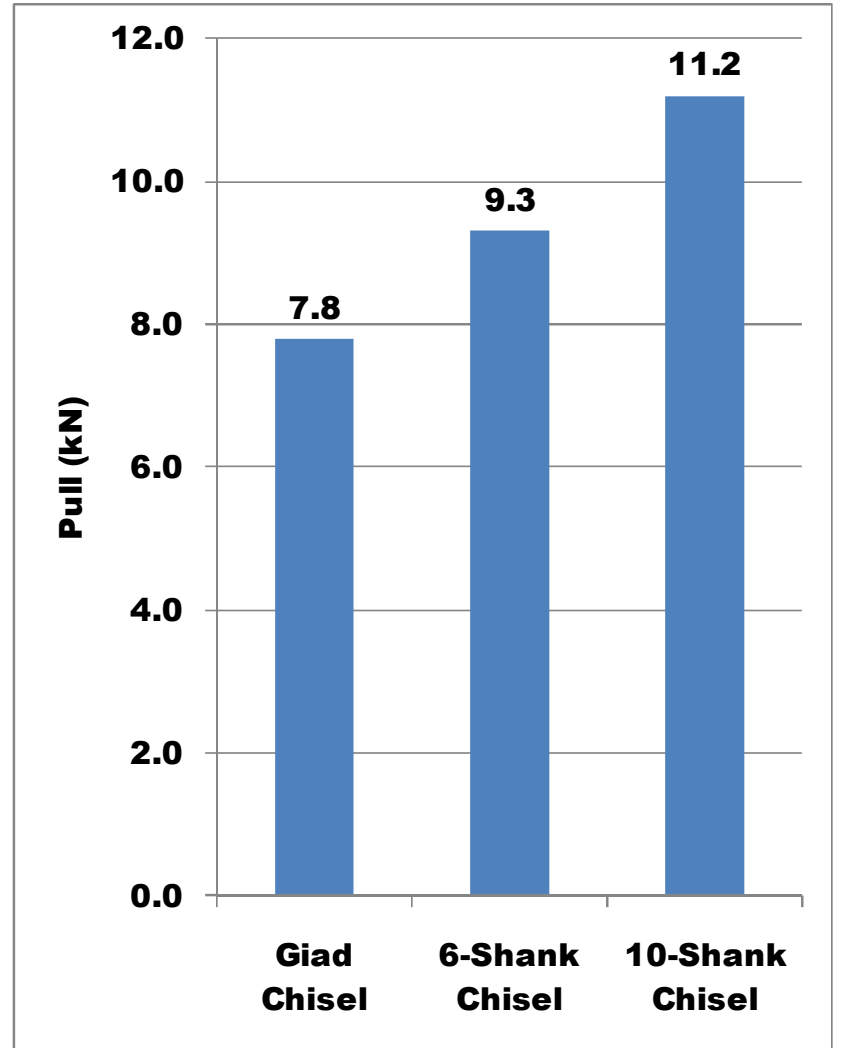

Figure 5: Drawbar pull of 3 chisel plows in sugarcane estates in Sudan

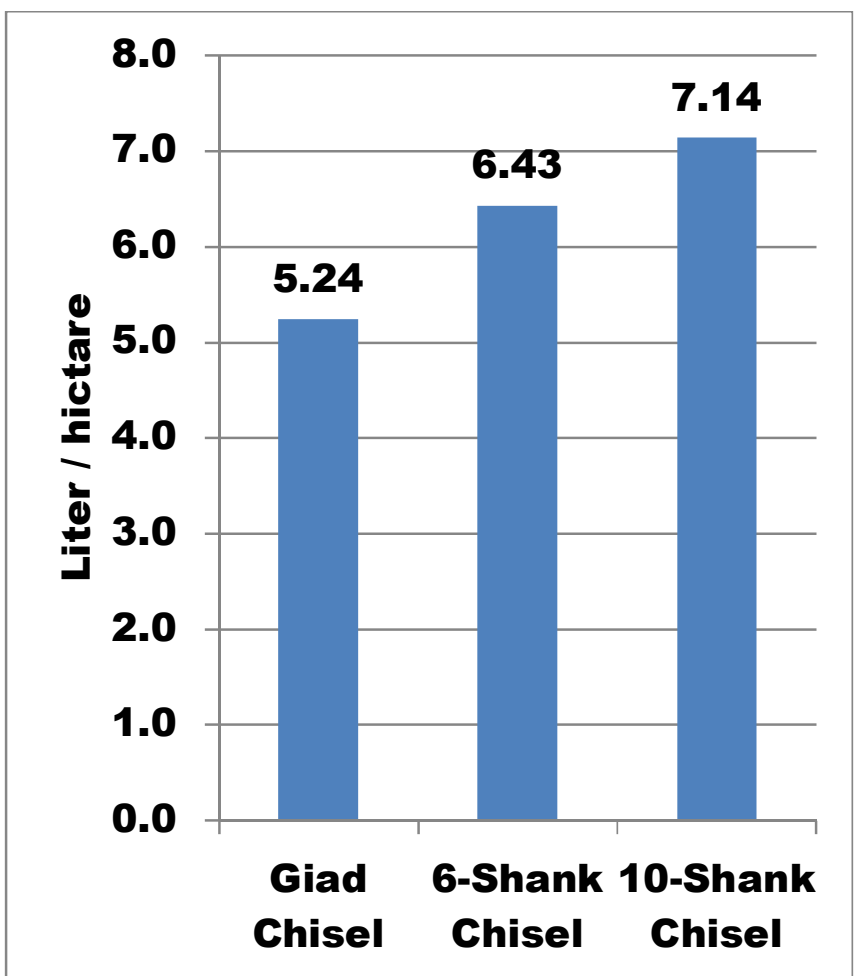

Figure 6: Fuel consumption for 3 chisel plows in sugarecane estates in Sudan 


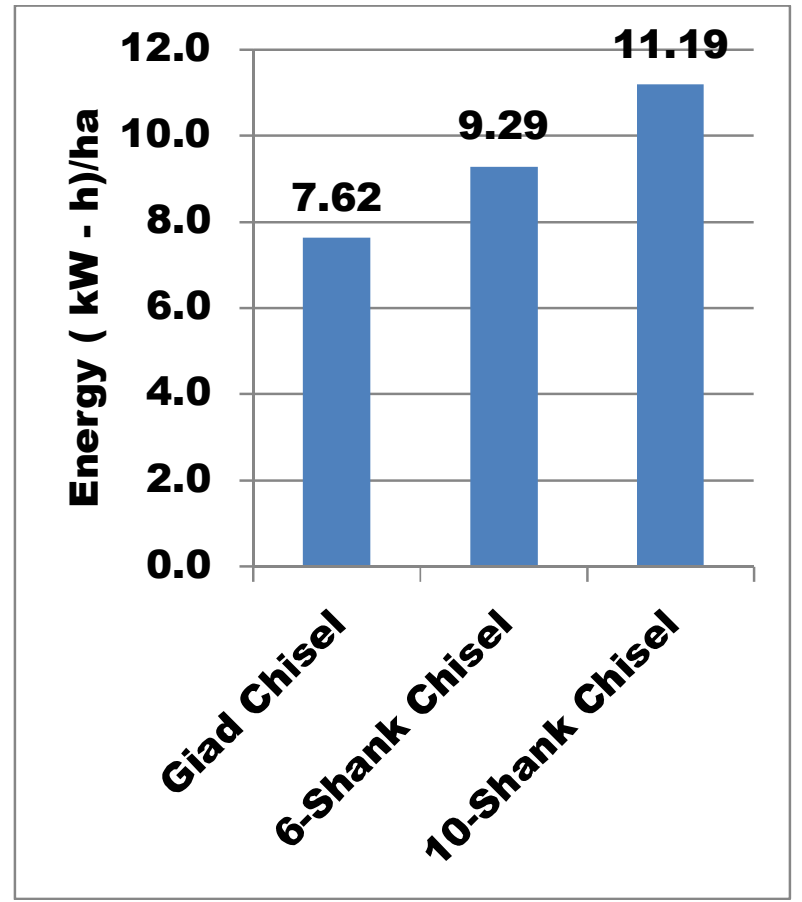

Figure 7: Energy requirement of 3 chisel plows on sugarcane estates in Sudan

Simple calculations based on data of Figure 4 showed that Giad chisel was of 3.8 and $7.6 \%$ higher field capacity than the 6- and 10-shank chisel plows, respectively. However, field capacity under the study conditions was mainly a function of implement width and work speed. The three implements were of the same width. No difference in the work speed was expected because the tractor engine was of $97 \mathrm{~kW}$, available drawbar power was $58.2 \mathrm{~kW}$ \{on firm surfaces according to Deere \& Company (1993), drawbar power $=0.6 \times$ engine power $\}$ while the required drawbar power could be around $38.9 \mathrm{~kW}\{(11.2 \mathrm{kN} \times 12.5 \mathrm{~km} / \mathrm{h}) / 3.6\}$.
Under such a loading, the tractor could pull the three implements at the same speed and accordingly field capacity should be similar. Nevertheless, average work speed of the 10-shank chisel was about $5 \%$ lower than that of the other two plows. Giad chisel was lowest in weight, followed by the 6-shank and then the 10-shank chisels as shown in Table 3. Light weight allowed easy raising and lowering of the implements during operation and allowed easy turning at the ends of the field. Effect of the implement weight in addition to that of speed could probably explain the encountered differences in actual field capacity.

Table 3: Weight of chisel plows

\begin{tabular}{|l|l|l|l|}
\hline Implement & $\begin{array}{l}\text { Giad chisel } \\
\text { plow }\end{array}$ & $\begin{array}{l}\text { 6-shank } \\
\text { chisel plow }\end{array}$ & $\begin{array}{l}10 \text {-shank chisel } \\
\text { plow }\end{array}$ \\
\hline Weight (kgf) & 240 & 270 & 550 \\
\hline
\end{tabular}

Three shanks per furrow ( $30 \mathrm{~cm}$ between shanks), as it was the arrangement with Giad and the 6 -shank chisels, were adequate to fully loosen the furrow surface while allowing easy flow of soil and trashes between the shanks. 5 shanks per furrow $(15 \mathrm{~cm}$ between shanks) as it was the arrangement with the 10-shank chisel, did not offer enough clearance to ease the flow of soil and trashes. In spite of that, the resulting furrow surface was similar to that produced by 3 shanks per furrow. Each of the three plows fully loosened the furrow surface to allow easy reformation of the ridge and furrow system. According to Deere \& Company (1993), for chisel plows, one shank per foot $(305 \mathrm{~mm})$ on the frame is a common arrangement. According to this statement and in the light of the resulting furrow condition, 5-shanks per furrow seemed an unjustifiable arrangement.
From Fig. 5, the 6-shank and 10-shank chisels respectively required $19 \%$ and $43 \%$ higher draft in comparison to Giad Plow. Tillage is exerting pressure on the soil. The reaction of the soil to the applied pressure is very much influenced by its moisture content. Dry soil easily flows over the tool without changing its geometry or causing bluntness of the cutting edge, Baver et al. (1972). As moisture content increases, a plastic soil becomes adhesive and sticks to tillage tools or foreign bodies. A layer of soil builds up along the surface of the tool and acts as a rigid body driven through the soil mass. Practically, this causes the tool to be blunt and require

higher power to cut through and move the soil, Gill and Vanden Berg (1976). According to this statement and under the effect of moisture content shown in Table 2, 
soil layers sticking on shanks and causing bluntness of their cutting parts made the 10-shank chisel require higher draft than the two 6-shank chisels.

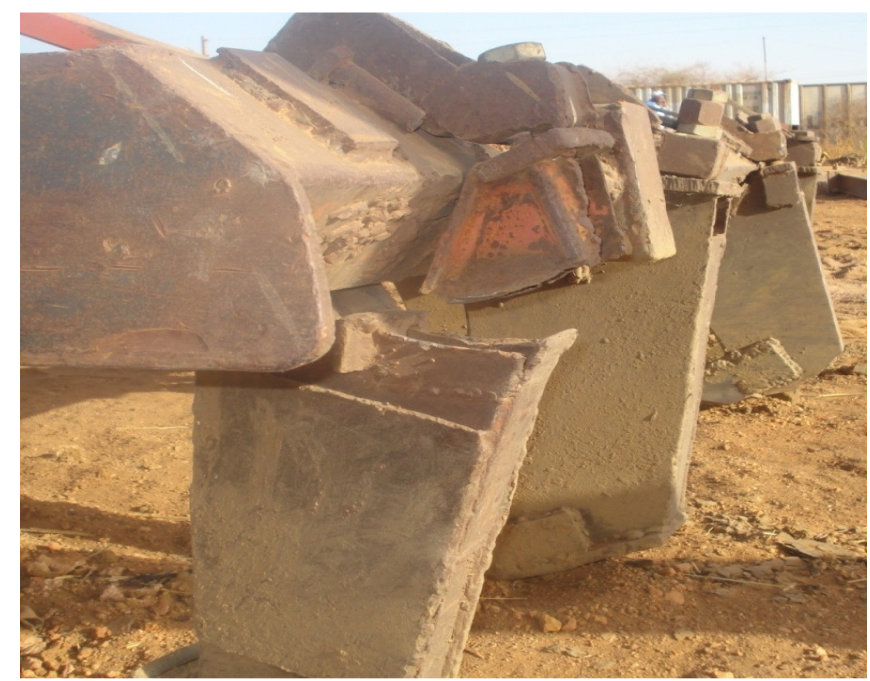

Figure 8: Lack of a protection device damaged a shank of a chisel plow

The difference in draft between Giad chisel (6 shanks) and the local 6 -shank chisel could be attributed to design features. Giad chisel was a properly manufactured implement with approximately curved shanks of alloy steel casting. The angle between the face of the chisel point and the horizontal (lift or rake angle) was 23 degrees. The 6-shank and 10-shank chisels were crudely fabricated from commercial steel (mild steel) using almost only cutting torches and arc welding equipment. The shanks were of different sizes (Figure 1 and Figure 2) and sometimes of different lift angles. Moreover, cutting points of the same chisel plow could have different lift angle as could be seen on the front and rear shanks of the plow shown in Figure (9).
However lift angles of locally fabricated plows were approximately 40 to 60 degrees. According to Deere \& Company (1993), tests showed that minimum draft of such tools as chisel plows and subsoilers occurred when the lift angle was 20 degrees. Shattering occurs with the least effort when the tool is applying a lifting force, rather than cutting horizontally or pushing vertically against the soil. Thus curved shanks are ideally suited to provide optimum soil fracturing with reduced draught. Curved shanks were reported to consume about $28 \%$ less power than straight shanks, Kepner et al. (1982). Therefore, difference in draft between Giad chisel and the local 6-shank chisel could be attributable to shape of shank and lift angle.

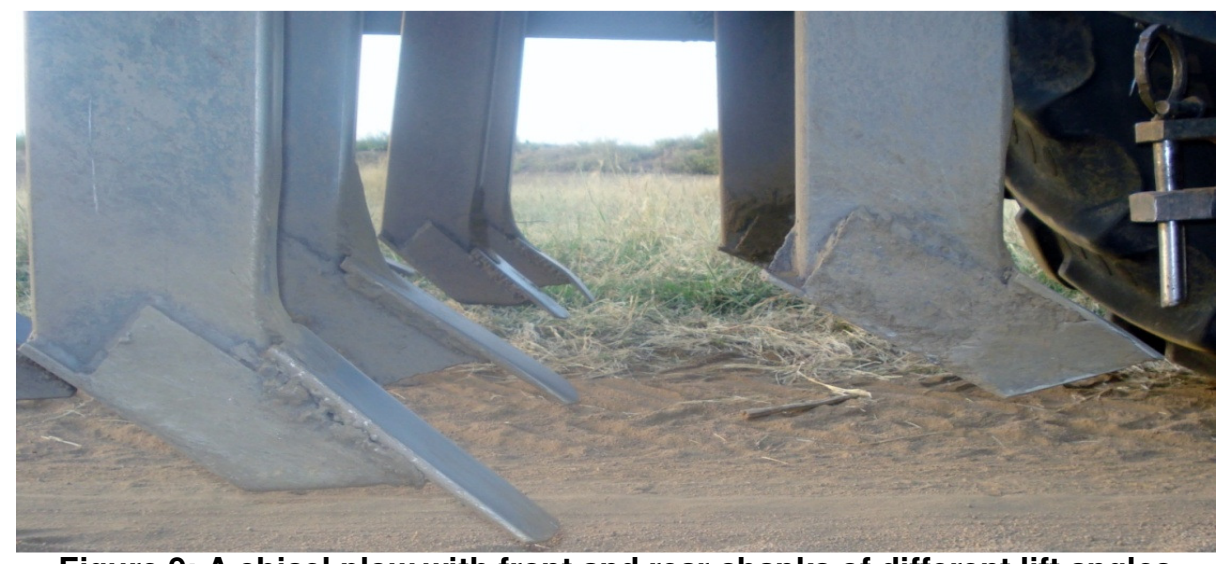

Figure 9: A chisel plow with front and rear shanks of different lift angles

Another feature that characterized Giad plow was a shear bolt that represented a safety device against shock loads. The need for a safety device was not taken into account in the fabrication of the other two chisel plows. Under normally encountered loads, damages in plow frames, shanks (Figure 8) and tractor centre link (screw link) were frequent. Repair of such damages was time consuming and greatly affected availability of the implements for field work. On the other hand, shear bolts in Giad plow made it safer to use and very much increased the availability of the machine for field work. During the study period, only two shear bolts failed and required only a few minutes to replace without further damage to other components. 
Energy required per hectare (Fig 7) was a parameter that included draft, speed of operation and area covered during a specified unit of time. The 6 - and 10 - shank chisels required $22 \%$ and $47 \%$ higher energy than that required by Giad chisel. Difference in energy requirement was reflected in fuel consumption per unit area. The 6- and 10- shank chisels were of respectively $22.7 \%$ and $36.4 \%$ higher fuel consumption per hectare.

\section{CONCLUSIONS}

$>$ A 2-furrow chisel plow with 3 shanks per furrow and $30 \mathrm{~cm}$ between shanks was adequate to loosen inter-rows of the ratoon cane fields.

$>$ Giad chisel plow outperformed locally fabricated chisel plows in energy components. In comparison to locally fabricated 2-furrow chisels with 6 and 10 shanks the Giad plow required in respective order, 84 and $70 \%$ lower drawbar pull, 81.4 and $73 \%$ lower fuel per hectare, and 82 and $68 \%$ lower energy in $(\mathrm{kW}$ h) / ha.

$>$ Locally fabricated plows lack protection devices against shock loads. The consequences were damages in main plow components and the need for relatively long time to repair in comparison to that required to replace shear bolts in Giad chisel.

\section{ACKNOWLEDGEMENT}

It is necessary to state here that the authors were entrusted by the General Manager of the Sudanese Sugar Company, to undertake a study of the agricultural machinery for cane production in the fields of the company. Locally fabricated chisel plows was one of the study topics. The authors would like here to express their deep appreciation for the support of the general manager, the factory managers of Sinnar, and Asalya and their field managers who offered all possible help to enable the group carry out this work. Thanks of the group were well deserved by the General Manager of Giad Company for Tractors \& Agricultural Equipment for supplying the group with the chisel plow used in this study.

\section{REFERENCES}

Baver, L.D., Gardner, W. H., Gardner, W. H., (1972). Soil Physics, $4^{\text {th }}$ edition. Wiley, New York.

Deer \& Company, Tillage: A practical guide to latest tillage methods, conservation planning, crop residue management, and solutions to soil problems. Third edition. Deer and Company Service Publications, Moline, Illinois, USA, 1993.

Gill, W. R., and G. E. Vanden Berg, (1976). Soil dynamics in tillage and traction. USDA Agriculture Handbook No. 316.

Hammad, E, A., (2012). Tractors for Cane Fields in Sudan. Sudan Engineering Society Journal, Vol. 58 (2): 1- 8, 2012.

Kepner, R. A., R. Bainer and E. L. Barger, (1982). Principles of farm machinery, third edition, third reprint, the AVI Publishing company, Inc. USA.

Landers A. (2000). Farm Machinery: Selection, Investment and Management. Farming

Press, UK,

Wikipedia $_{1}$, the free encyclopaedia (accessed on 10/6/2013):

http://en.wikipedia.org/wiki/Mild_steel\#Mild_steel

Wikipedia $_{2}$, the free encyclopaedia (accessed on 10/6/2013):

http://en.wikipedia.org/wiki/Spring_steel 